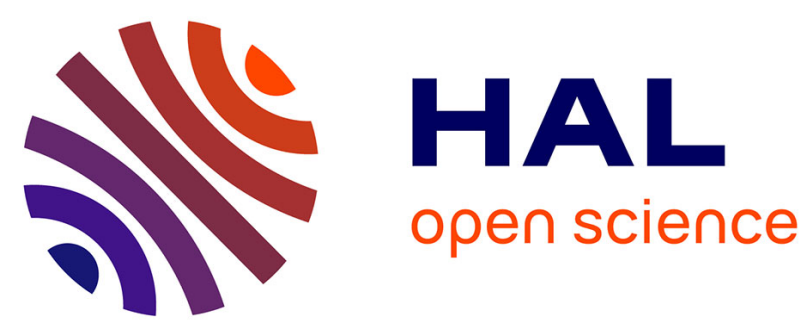

\title{
What do we need to predict groundwater nitrate recovery trajectories?
}

Camille Vautier, Tamara Kolbe, Tristan Babey, Jean Marçais, Benjamin W

Abbott, Anniet M. Laverman, Zahra Thomas, Luc Aquilina, Gilles Pinay, Jean-Raynald de Dreuzy

\section{To cite this version:}

Camille Vautier, Tamara Kolbe, Tristan Babey, Jean Marçais, Benjamin W Abbott, et al.. What do we need to predict groundwater nitrate recovery trajectories?. Science of the Total Environment, 2021, 788, pp.147661. 10.1016/j.scitotenv.2021.147661 . insu-03224195

\section{HAL Id: insu-03224195 https://hal-insu.archives-ouvertes.fr/insu-03224195}

Submitted on 11 May 2021

HAL is a multi-disciplinary open access archive for the deposit and dissemination of scientific research documents, whether they are published or not. The documents may come from teaching and research institutions in France or abroad, or from public or private research centers.
L'archive ouverte pluridisciplinaire HAL, est destinée au dépôt et à la diffusion de documents scientifiques de niveau recherche, publiés ou non, émanant des établissements d'enseignement et de recherche français ou étrangers, des laboratoires publics ou privés. 


\section{Journal Pre-proof}

What do we need to predict groundwater nitrate recovery trajectories?

Camille Vautier, Tamara Kolbe, Tristan Babey, Jean Marçais, Benjamin W. Abbott, Anniet M. Laverman, Zahra Thomas, Luc Aquilina, Gilles Pinay, Jean-Raynald de Dreuzy

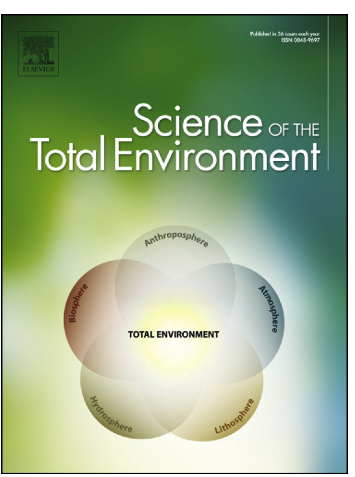

PII: $\quad$ S0048-9697(21)02732-7

DOI: $\quad$ https://doi.org/10.1016/j.scitotenv.2021.147661

Reference: $\quad$ STOTEN 147661

To appear in: $\quad$ Science of the Total Environment

Received date: $\quad 2$ March 2021

Revised date: $\quad 16$ April 2021

Accepted date: $\quad 5$ May 2021

Please cite this article as: C. Vautier, T. Kolbe, T. Babey, et al., What do we need to predict groundwater nitrate recovery trajectories?, Science of the Total Environment (2021), https://doi.org/10.1016/j.scitotenv.2021.147661

This is a PDF file of an article that has undergone enhancements after acceptance, such as the addition of a cover page and metadata, and formatting for readability, but it is not yet the definitive version of record. This version will undergo additional copyediting, typesetting and review before it is published in its final form, but we are providing this version to give early visibility of the article. Please note that, during the production process, errors may be discovered which could affect the content, and all legal disclaimers that apply to the journal pertain.

(C) 2021 Published by Elsevier B.V. 


\section{What do we need to predict groundwater}

\section{nitrate recovery trajectories?}

Camille Vautier $^{a} *$, Tamara Kolbe ${ }^{b}$, Tristan Babey $^{c}$, Jean Marçais ${ }^{d}$, Benjamin W. Abbott ${ }^{e}$,

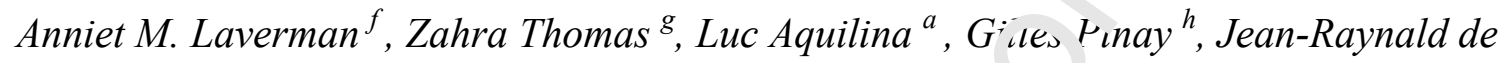
$\operatorname{Dreuzy}^{a, i}$

${ }^{a}$ Univ Rennes, CNRS, Géosciences Rennes, L MR 6118, 35000 Rennes, France

${ }^{\mathrm{b}}$ Chair of Hydrogeology and Hydrochemistry, F.c lty of Geoscience, Geoengineering and Mining, Institute of Geology, Technischє Unı versität Bergakademie Freiberg, 09599 Fre oer s, Germany

${ }^{c}$ Department of Earth System Scic nce, Stanford University, Stanford, CA 94305, USA

${ }^{\mathrm{d}}$ Institut National de Recherche e 1 s ciences et Technologies pour l'Environnement et l'Agriculture (Irstea), RiverLy, Cen're de Lyon-Villeurbanne, 69625 Villeurbanne, France

${ }^{\mathrm{e}}$ Department of Plant and W:-11..e Sciences, Brigham Young University, Provo, UT 84602, USA

${ }^{\mathrm{f}}$ Univ Rt. nts, CNRS, Ecobio, UMR 6553, 35000 Rennes, France

${ }^{g}$ Institut National de la Recherche Agronomique (INRA), Sol Agro et Hydrosystème Spatialisation, UMR 1069, Agrocampus Ouest, 35042 Rennes, France

${ }^{\mathrm{h}}$ Environnement, Ville et Société, EVS - UMR5600 CNRS, Lyon France

${ }^{\mathrm{i}}$ Univ Rennes, CNRS, OSUR (Observatoire des sciences de l'univers de Rennes), UMS 3343, 35000 Rennes, France 


\section{Highlights}

- Nitrate recovery trajectories were predicted based on a few key-parameters.

- Two age tracers are necessary to predict groundwater nitrate concentration.

- The stratification of denitrification controls the nitrate dynamic in the aquifer.

- Uncertainty about past nitrogen inputs may not alter the predictions.

\section{Abstract}

Nitrate contamination affects many of the Earth's aquifers ind iurface waters. Large-scale predictions of groundwater nitrate trends normally req' $n \cdot t^{\prime}$ e characterization of multiple anthropic and natural factors. To assess different app oac es for upscaling estimates of nitrate recovery, we tested the influence of hydrolo a al, historical, and biological factors on predictions of future nitrate concentration 1 . aquifers. We tested the factors with a rich hydrogeological dataset from a heteroge ${ }^{\text {' }}$ ously fractured bedrock catchment in western France. A sensitivity analysis periv med on a calibrated model of groundwater flow, denitrification, and nitrogen ir pus revealed that trends in nitrate concentration can effectively be approximated vitı a limited number of key parameters. The total mass of nitrate that entered the aqu fer since the beginning of the industrial period needs to be characterized, but the st ape of the historical nitrogen input time series can be largely simplified without substantially altering the predictions. Aquifer flow and transport processes can be represented by the mean and standard deviation of the residence time distribution, offering a tractable scaling tool to make reasonable predictions at watershed or regional scales. Apparent sensitivity to denitrification rate was primarily attributable to time lags in oxygen depletion, meaning that denitrification can be simplified to an ON/OFF process, defined only by the time needed to transfer nitrate to the hypoxic reactive layer. Obtaining these key-parameters at large scales is still challenging with currently available information, 
but the results are promising regarding our future ability to predict nitrate concentration with integrated monitoring and modeling approaches.

\section{Graphical abstract}

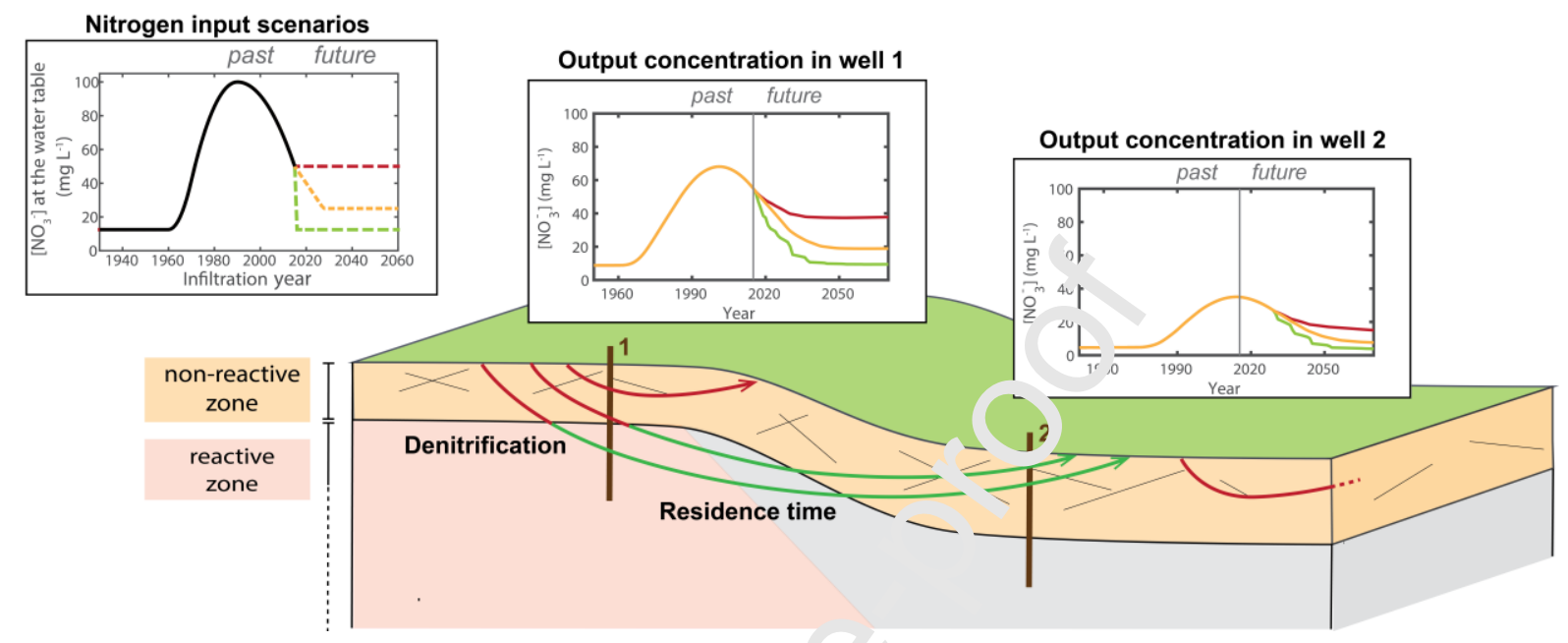

\section{Key-words}

Groundwater, nitrate, denitrification, el. ophication, residence time, predictions 


\section{Introduction}

Human activity has more than doubled reactive nitrogen delivery to Earth's ecosystems, creating eutrophic (over-fertilized) conditions in aquatic and coastal environments around the world (Galloway et al. 2008; Kronvang et al. 2005). In the past several decades, widespread efforts have been made to reduce human nutrient loading to protect freshwater resources and ecosystems (Abbott et al. 2018; Boers 1996; Kronvang et al. 2008; Kronvang et al. 2005; Steffen et al. 2015). However, naíu.al systems often respond to changes in nutrient inputs with a time lag, making recovery i...jectories difficult to predict. This complicates the evaluation of mitigation strategis and can even imperil public and political support for investment in mitigation (Hamiltc-2012; Kronvang et al. 2005; Meals et al. 2010; Van Meter and Basu 2015; Van Mettr an 1 Basu 2017). In many catchments, long time lags mean that the agricultura pr icies we choose today will affect nitrogen concentration in surface and groundw iter for several decades (Ehrhardt et al. 2019; Thomas and Abbott 2018; Van Meter anc 3asu 2015). Thus, improving predictions of nutrient recovery timelines following cifte:-ent agricultural scenarios is an important ecological and socioeconomic goal (Kolbe at a . 2019; Le Moal et al. 2019; Marcais et al. 2018; Minaudo et al. 2019).

Nitrogen can be stored for several years to several decades in different compartments of surface and subsurface ecosystems, leading to what is called a nitrogen legacy (Ehrhardt et al. 2019; Hrachowitz et al. 2015; Van Meter et al. 2017; Van Meter et al. 2016). Apart from the soil (Sebilo et al. 2013), one of the main drivers of nitrogen legacy is groundwater. Because aquifers contain two orders of magnitude more water than all rivers and lakes (Abbott et al. 2019), groundwater nitrogen can be stored for decades before reaching the surface (Fenton et al. 2011; Wendland et al. 2002). However, because the major form of groundwater nitrogen is nitrate $\left(\mathrm{NO}_{3}{ }^{-}\right)$, microbial activity during groundwater storage and 
transport can reduce nitrogen stocks via anaerobic catabolism (denitrification), which eventually transforms $\mathrm{NO}_{3}{ }^{-}$into $\mathrm{N}_{2}$ gas (Green et al. 2016; Kolbe et al. 2019; Korom 1992). As a result, groundwater circulation exerts a dual control on $\mathrm{NO}_{3}{ }^{-}$pollution: it creates a delay or time lag between inputs and outputs and it directly reduces the $\mathrm{NO}_{3}{ }^{-}$stock in the system.

Predicting $\mathrm{NO}_{3}{ }^{-}$recovery trajectory for a given aquifer requires information about the past and future nitrogen inputs, the water residence times, and the rate of nitrate removal (Kolbe et al. 2019; Małoszewski and Zuber 1982; Van Meter and Basu 2015). Each of these three functions is defined by a set of parameters that need to be quantified. However, quantifying these functions is challenging because c a lack of data at appropriate spatiotemporal scales (Abbott et al. 2016; Frei et a1 ¿2?0; McDonnell et al. 2007). The information is only available in few study sites wh re neasurements and modelling efforts have been coupled (Böhlke and Denver 1995; G. Ser. et al. 2016; Kolbe et al. 2019; Paradis et al. 2017; Singleton et al. 2007; Tesorier эn $\_$Puckett 2011). Because mitigation strategies are often decided and implemented at lary scales such as regions or nations (Kronvang et al. 2005; US EPA 2008), large-scale ${ }_{1}$ rec $^{\prime i}$,tions of removal and storage capacities are needed to set realistic expectations of $\mathrm{n}_{\mathrm{h}}$ itigation actions and time frame of recovery and to predict ecosystem vulnerability to nu. ni nt loading (Abbott et al. 2018; Pinay et al. 2015).

In this context, we $\cdot$ se ted the sensitivity of $\mathrm{NO}_{3}{ }^{-}$recovery predictions based on simple but robust hydrological parameters in a well-studied unconfined fractured bedrock aquifer. We performed a sensitivity analysis to identify the key parameters, including both anthropic and natural drivers that need to be constrained to predict the future nitrate trajectories in the aquifer. Our immediate goals were to 1 . forecast groundwater nitrate trajectories for different loading scenarios, 2. determine the dominant controls on groundwater nitrate concentration, and 3. assess how much hydrological detail is needed to make accurate predictions of largescale biogeochemical patterns in space and time. 


\section{Material and methods}

Based on a reference model including groundwater flow, nitrate degradation and reconstructed past nitrogen inputs, we predicted the evolution of nitrate concentration in 16 wells over a well-studied small agricultural catchment. We then performed a sensitivity analysis on the predicted concentrations to identify the primary controls on nitrate pollution in groundwater. Below, we describe the catchment, reference model, and methods used for the sensitivity analysis.

\subsection{Field site}

The study was conducted on a $35 \mathrm{~km}^{2}$ ag icultural catchment located near Pleine-Fougères, a small town in Brittany, Fran c. The catchment is part of the Zone Atelier Armorique (Thomas et al. 2019), a Lor o $10 \cdot m$ Socio-Ecological Research site (LTSER) (www.lter-europe.net). Like in most of $\mathrm{b}_{\mathbf{1}}$ :ttany, the study area has been subject to high inputs of organic and mineral fertil' $\angle \mathrm{e}$ - since the 1960's (Aquilina et al. 2012; Dupas et al. 2018; Poisvert et al. 2016). Aft r a peak of nitrogen inputs at the beginning of the 1990's, farmers slowly reduced their lı"tiizers use (Abbott et al. 2018).

Mean groundwa er 1 :charge was estimated at $167 \mathrm{~mm} \mathrm{y}^{-1}$ using the ISBA model (Noilhan and Mahfouf 19 96), slightly lower than the mean regional recharge of Brittany (Le Moigne 2009). Groundwater flows primarily through the weathered and fissured zones of a shallow, unconfined aquifer (Bernard-Griffiths et al. 1985; Wyns et al. 2004). Chlorofluorocarbons (CFCs) revealed typical mean residence times of several decades ( 30 years), indicating a large-capacity aquifer relative to surface outflows (Kolbe et al. 2016; Marcais et al. 2018). However, the aquifer is marked by high spatial variability of residence and denitrification times, resulting in strong heterogeneity of groundwater $\mathrm{NO}_{3}{ }^{-}$ concentration (Kolbe et al. 2019; Kolbe et al. 2016). 
Data from the French geological survey indicate that the weathered zone thickness ranges from 0 to $40 \mathrm{~m}$ within the catchment area, with a mean depth of $9 \mathrm{~m}$. The underlying fractured bedrock is less conductive but much thicker with a mean thickness of $48 \mathrm{~m}$ (Kolbe et al. 2016). The aquifer extends from a granitic intrusion in the south to a schist bedrock in the north, with groundwater flowing northward (Kolbe et al. 2016). A marked altitude difference of $90 \mathrm{~m}$ at the geological contact between schist and granite creates springs at the foot of the slope (Kolbe et al. 2016).

We used groundwater chemistry data from previons sudies in the catchment. Specifically, 16 privately owned wells ( $28 \mathrm{~m}$ to $98 \mathrm{~m}$ ' $\mathrm{ree}^{\prime}$ ' were sampled at three timeperiods (December 2014, March 2015, and October 2n1, , to characterize the hydrochemistry of the aquifer (See Kolbe et al. 2016 for details).

\subsection{Reference model}

The nitrate concentration in the aquifer through time, $c(t)$, results from the convolution of the nitrate input tim 2 se ies at the water table $c_{0}$, the groundwater residence time distribution $p$, and the pro $\mathrm{O}_{1}$ ion of nitrate remaining after denitrification for a time $\tau$ in the saturated zone $r_{\mathrm{NO}}(\tau)$, Mat szewski and Zuber 1982):

$$
c(t)=\int_{0}^{\infty} c_{0}(t-\tau) p(\tau) r_{N O 3}(\tau) d \tau
$$

\subsubsection{Residence time distributions}

We modelled groundwater circulation with a steady-state, three-dimensional, flow and transport model previously developed for the site by Kolbe et al. (2016) in the FEFLOW software environment (Diersch 2013). To limit boundary effects, the modeled zone was substantially larger $\left(76 \mathrm{~km}^{2}\right)$ than the hydrological catchment $\left(35 \mathrm{~km}^{2}\right)$. The mean annual recharge $(167 \mathrm{~mm} / \mathrm{y})$ was applied uniformly on the top layer of the model. Flow lines were 
calculated using the particle tracking algorithm of FEFLOW (Diersch 2013). Hydraulic conductivity and effective porosity were calibrated using base-flow stream discharge and groundwater age data. The base flow stream discharge at the outlet of the catchment, interpreted as the catchment's mean annual groundwater discharge, was derived from hydrograph separation of long-term stream discharge time series. Groundwater discharge was estimated at $4.5 \times 10^{6} \mathrm{~m}^{3} \mathrm{y}^{-1}$. Mean groundwater ages were determined in the sampling wells based on CFC-12, an anthropogenic gas used as age tracer for groundwater that infiltrated after 1950 (Ayraud et al. 2008; Busenberg and Plummer 199)' ( $5 \mathrm{C}-12$ measurements were performed on grab samples in the CONDATE-EAU platf srı. of the University of Rennes 1. For each of the 16 wells, residence time distributions of $t_{1}{ }^{2}$ groundwater were extracted from the calibrated model by intercepting the flow lines jolı. $\sigma$ through the full depth of the well handled as a fully penetrating well. Times we a ar ked from the water table of the aquifer to a sampling zone around the well. ' ' ' se sampling zone was chosen small enough to characterize the well capture and la. se enough to build representative residence time distributions. Representativity $\mathrm{w}^{\sim} \mathrm{r}^{\mathrm{n}}$.hed for some $10^{6}$ flow lines flux-weighted to the recharge (Kolbe et al., 201i). Well locations and parameters of the residence time distributions are given as $\operatorname{cup}_{\mathfrak{r}}^{1 /}$ mentary material by Figure S1 and Table S1.

\subsubsection{Denitrification}

We applied a first order reaction to each flow line for oxygen $\left(\mathrm{O}_{2}\right)$ and $\mathrm{NO}_{3}{ }^{-} \cdot \mathrm{O}_{2}$ concentration at the water table, $O_{2}$ water table, was set at $7 \mathrm{mg} \mathrm{L}^{-1}$, corresponding to the concentration measured in shallow piezometers. $\mathrm{O}_{2}$ consumption in the saturated zone was defined by an apparent degradation time $\tau_{O 2}$ with $r_{O 2}(t)$ the proportion of $\mathrm{O}_{2}$ remaining after at time $t$ :

$$
r_{O 2}(t)=\exp \left(-\frac{t}{\tau_{O 2}}\right)
$$


Because $\mathrm{O}_{2}$ is a more powerful electron acceptor than $\mathrm{NO}_{3}{ }^{-}$, denitrification can start only after most $\mathrm{O}_{2}$ has been consumed (Green et al. 2016; Kolbe et al. 2019; Korom 1992). Here we considered that denitrification started when $\mathrm{O}_{2}$ concentration was below $2 \mathrm{mg} \mathrm{L}^{-1}\left(\mathrm{O}_{2}\right.$ threshold). Thus, the amount of remaining nitrate $r_{\mathrm{NO}}$ is defined by two parameters: the time lag needed for the denitrification to begin, $t_{\text {lag }}$, which basically corresponds to the $\mathrm{O}_{2}$ degradation time, and the denitrification time itself, $\tau_{\mathrm{NO} 3}$, which described the rate of $\mathrm{NO}_{3}{ }^{-}$degradation once it has begun, that is after the $\mathrm{O}_{2}$ threshold.

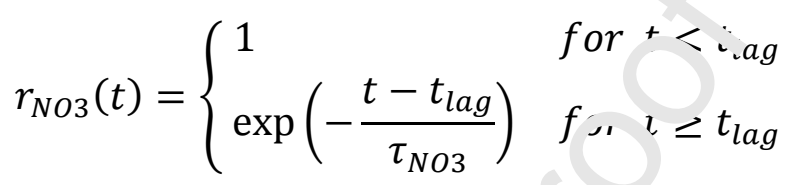

with: $\quad t_{\text {lag }}=\tau_{O 2} \ln \left(\frac{O_{2} w \cdot \text { cer }}{\left.O_{2} \text { thr. } \frac{\text { avle }}{\text { nold }}\right)}\right)$

The chemical system is fully defined by the $t \cdot r$ e equations (2), (3) and (4). The reaction times for $\mathrm{O}_{2}$ and $\mathrm{NO}_{3}{ }^{-}$were calibrated iro a the sampled $\mathrm{O}_{2}, \mathrm{NO}_{3}{ }^{-}$and $\mathrm{N}_{2}$ concentrations (Kolbe et al. 2019). Values of $t_{\text {lag }}$ and ${ }^{-}{ } O 3$ are given as supplementary materials by Table S1.

\subsubsection{Past nitrogen inputs}

The nitrogen input timı series was reconstructed specifically for our catchment by Kolbe et al. (2019) from the $\left.{ }_{-}^{-}\right\lrcorner$wells' $\mathrm{NO}_{3}{ }^{-}, \mathrm{N}_{2}$, and groundwater age data. Denitrification produces $\mathrm{N}_{2}$, creating $a_{1}$. excess of dissolved $\mathrm{N}_{2}$ relative to the atmosphere in groundwater, allowing estimation of the amount of degraded $\mathrm{NO}_{3}{ }^{-}$(Aeschbach-Hertig et al. 1999). The initial concentration of $\mathrm{NO}_{3}{ }^{-}$entering the saturated zone was calculated by adding the amount of degraded $\mathrm{NO}_{3}{ }^{-}$(estimated from the $\mathrm{N}_{2}$ excess) to the current $\mathrm{NO}_{3}{ }^{-}$concentration. Though land use in particular plots over the last several decades has rotated (Barbe et al. 2019), the overall catchment land use revealed that nitrogen inputs can be considered as spatially uniform (Kolbe et al. 2019), allowing the determination of a single $\mathrm{NO}_{3}{ }^{-}$input time series for the whole catchment. Using initial $\mathrm{NO}_{3}{ }^{-}$concentration and the residence time distribution in 
each well, we used an inverse method to reconstruct the past $\mathrm{NO}_{3}{ }^{-}$concentration chronicle at the water table (i.e. until 2015). This time series corresponds to the amount of $\mathrm{NO}_{3}{ }^{-}$entering the saturated zone. Therefore, it accounts implicitly for potential biogeochemical uptake in the unsaturated zone (Thomas and Abbott 2018). Hence, our study focuses only on the processes occurring in the saturated zone, unlike traditional time series based on land use data and agronomic statistics, which provide nitrogen surpluses in the soil (Oenema et al. 2003; Parris 1998; Poisvert et al. 2016; Salo and Turtola 2006).

\subsubsection{Future agricultural scenarios}

To forecast the $\mathrm{NO}_{3}{ }^{-}$concentration, we extended th $\cdot$ int ut time series $c_{0}$ into the future following three scenarios. The "reference" scenaric fo 'owed the current decreasing trend until stabilizing at $25 \mathrm{mg} \mathrm{NO}_{3}{ }^{-} \mathrm{L}^{-1}$. The "no $\mathrm{d}$ s`ease" scenario assumed the nitrate input stayed at its current value $\left(50 \mathrm{mg} \mathrm{L}^{-1}\right)$ רı. " the "immediate ban" scenario applied an

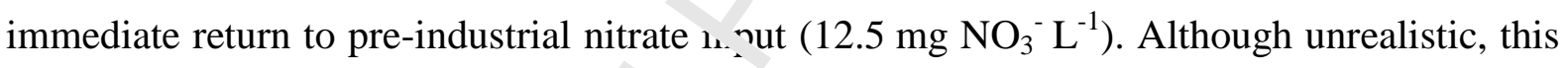
scenario highlights the nitrate legacy a $\urcorner$ d is impact on future nitrate concentrations.

\subsection{Sensitivity analysis}

We performed a svs ar atic sensitivity analysis on the future nitrate scenarios to evaluate the relative in. 'ence of residence time, denitrification, and past nitrogen input. As a sensitivity indicator, we used the nitrate concentration predicted for the year 2030 with a reference scenario assuming a progressive reduction of nitrogen inputs. We chose a 15-year period (2015 to 2030) to allow for the natural system to react to changes in nitrogen inputs, while still being short enough to be of interest for policy makers (Abbott et al. 2018; Choi et al. 2005). In the reference model, each of the parameters (residence time distribution, denitrification rate and duration, and nitrogen inputs) was modified individually in sequence. 
For each of the 16 wells, we compared the concentration predicted under the reference model with all actual parameters and the concentration predicted with modified parameters.

\subsubsection{Modification of residence time distributions}

Natural residence time distributions may take a broad variety of shapes even when their mean and standard deviation are fixed (Engdahl and Maxwell 2014; Ginn 1999; Leray et al. 2016; Marcais et al. 2015). To test the sensitivity of the predictions to the shape of the residence time distributions, we replaced the complex di tributions obtained from the calibrated simulations (Kolbe et al. 2016) with lumped param ter nodels (LPMs), that is with highly simplified analytical distributions. Two 1-param ter LPMs and four 2-parameters LPMs were tested (Table 1). The 1-parameter LFMs had the same mean as the actual distribution. The 2-parameter LPMs had the sam = mean and standard deviation as the actual distribution. 


\section{$\mathrm{N} \quad$ Lumped Parameter Model Expression}

$1 \quad$ Dirac (piston flow) $\quad p_{T}(t)=\delta(t-T)$

Exponential (exponential) $\quad p_{T}(t)=\frac{1}{T} \exp \left(\frac{-t}{T}\right)$

2 Inverse Gaussian (dispersion) $\quad p_{T, P e}(t)=\sqrt{\frac{T P e}{2 \pi t^{3}}} \exp \left(-\frac{P e(t-T)^{2}}{2 T t}\right)$

Shifted exponential

$$
p_{T, t_{0}}(t)
$$

(exponential piston flow) $\quad= \begin{cases}0 & \text { for } t<T-t_{0} \\ \frac{1}{t_{0}} \exp \left(-\frac{t-\left(-{ }^{+}\right)}{-}\right) & \text {otherwise }\end{cases}$

Uniform (linear piston flow) $\quad p_{T, \varepsilon}(t)= \begin{cases}\frac{1}{t} & \text { for }-\frac{\epsilon}{2} \leq t<T+\frac{\varepsilon}{2} \\ \vdots & \text { therwise }\end{cases}$

Gamma

$$
p_{T \sim}(+)=\frac{t^{\alpha-1}}{\left(\frac{T}{\alpha}\right)^{\alpha} \Gamma(\alpha)} \exp \left(-\frac{\alpha t}{T}\right)
$$

Table 1. Lumped parameter models $\mathrm{u} \cdot \mathrm{ed}$ in the sensitivity analysis. The left-hand column indicates the number of parameter ( $($ ) The names in brackets refer to those of Maloszewski and Zuber (1996). All LPM ex pressions involve the mean residence time $T$. Expressions of 2-parameters LPMs additio ally introduce the Peclet number $P e$ for the inverse gaussian model, the time lag $t_{0} \sim r$ in shifted exponential model, the range of explored times $\varepsilon$ for the uniform model, and the shape factor $\alpha$ for the gamma model.

\subsubsection{Modification of denitrification}

We postulated that denitrification starts only when the $\mathrm{O}_{2}$ concentration fell below $2 \mathrm{mg} \mathrm{L}^{-1}$. Therefore, the denitrification function was defined by the time lag needed for denitrification to begin, $t_{l a g}$, and the denitrification time itself, $\tau_{\mathrm{NO} 3}$ (equation 2). To test the impact of these two parameters on the nitrate concentration, we replaced the actual time lag $t_{\text {lag }}$ and the actual denitrification rate $\tau_{N O 3}$ determined for each well by their mean over the 16 
wells. In the 16 wells, $t_{\text {lag }}$ varied from 3 to $67 \mathrm{y}($ mean $=33 \mathrm{y})$ and $\tau_{N O 3}$ varied from 1 to $20 \mathrm{y}$ $($ mean $=4.7 \mathrm{y})$.

\subsubsection{Modification of past nitrogen inputs}

Regardless of the reconstruction method, nitrogen input time series contain uncertainties in their cumulated concentration (i.e. the total mass of nitrate that entered the system since the beginning of the industrial period) and in their shape, especially related to the position of the peak of nitrate inputs (Payraudeau et a'. 2007). We analyzed model sensitivity to the total input mass by modifying the cumula ed concentration between 1960 (beginning of the increase in the nitrate inputs) and $201 \leqslant$ (en 1 of the sampling campaigns). We also tested the impact of the shape of the time serı s by simplifying it to a rectangular distribution (a plateau shape rather than curved).

\section{Results}

\subsection{Nitrate concentratior $s$ predicted by the reference model}

Groundwater nitrate ccen cen ration was predicted by the reference model for the three future loading scenarios pres ant $: \mathrm{d}$ in section 2.2.4. (Figure 1). Results are shown for the years 2020, 2030 and 205v, s...sponding respectively to 5, 15 and 35 years ahead of the last measurement campaign (2015).

In three wells, the legacy effect is so strong that even with an "immediate ban" scenario, the nitrate concentration would increase between 2020 and 2030. On a time range of 15 years, their responses do not even depend on the evolution scenario and are only controlled by past inputs. Generally, differences between the three scenarios increase with time, as increasing quantities of water infiltrated after the beginning of the mitigation scenarios reach the wells. 
Nevertheless, whatever the scenario, nitrate concentration is highly heterogeneous with a consistent spatial pattern throughout the catchment. In 2030, the concentration is close to 0 in some wells, while the maximum concentration is still higher than the guideline value of $50 \mathrm{mg} \mathrm{L}^{-1}$ recommended by the World Health Organization. The same nitrate input time series was applied to the whole catchment, so the heterogeneity in the output concentrations results from spatial variability of residence times and denitrification in the aquifer. This illustrates the wide range of residence times and denitrification rates existing in fractured bedrock aquifers such as the one studied here, and their impant On $^{\text {present }}$ and future nitrate concentration. Consequently, future nitrate concentratior $\$ \perp^{\prime}$ aquifers cannot be predicted straightforwardly from future agricultural scenarine Dredictions require not only to characterize past and future nitrate inputs, but lsc groundwater residence times and denitrification capacities.

To investigate the relative impor $\urcorner n r e$ of anthropic and natural parameters, we further performed a sensitivity analysis on the nncentrations predicted with the reference scenario in 2030 (enlarged map on Figure 1). 


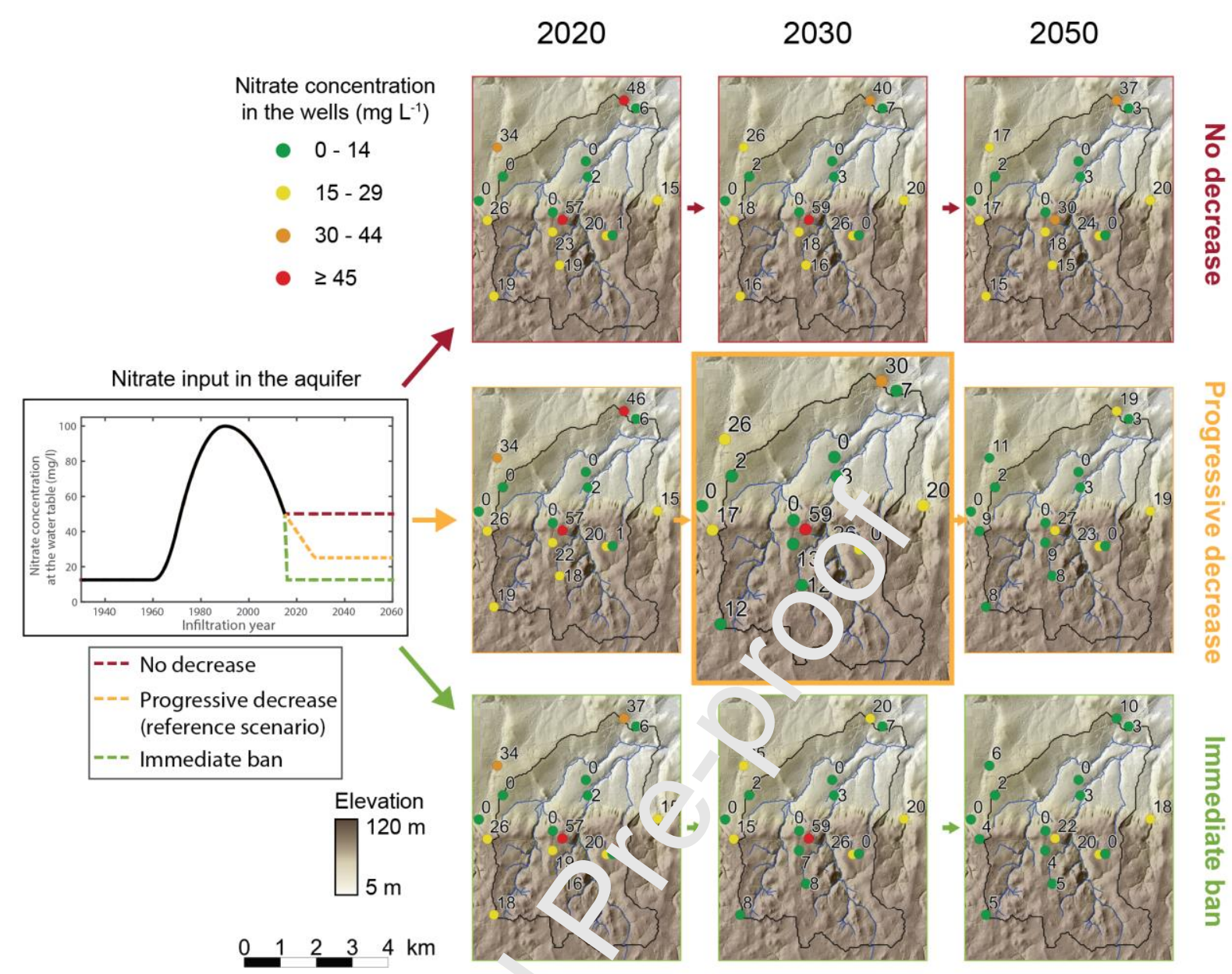

Figure 1. Predicted nitrate concen $r$ ti ms in the 16 wells following the three agricultural scenarios described in section 2.4.1 and recalled on the left. Concentrations were predicted for 2020, 2030 and 2050 sin; the reference model. The somewhat enlarged map in the middle displays the cencentrations on which the sensitivity analysis was further performed, ie the concentrations predicted for 2030 with the reference scenario.

\subsection{Sensitivity analysis}

The primary results of the sensitivity analysis are presented in Figure 2 (additional details in Figure S2). For each tested parameter, the nitrate concentration predicted for 2030 in the 16 wells with the modified parameter are plotted against the nitrate concentration predicted for 2030 with the reference model. Deviation from the 1:1 line and systematic overprediction or underprediction indicate the degree of sensitivity of the predictions to the 
modified parameter. The larger the deviation, the higher the sensitivity. This analysis demonstrates the relative importance of biological activity, groundwater residence time, and nitrate input time series to future nitrate concentration. 


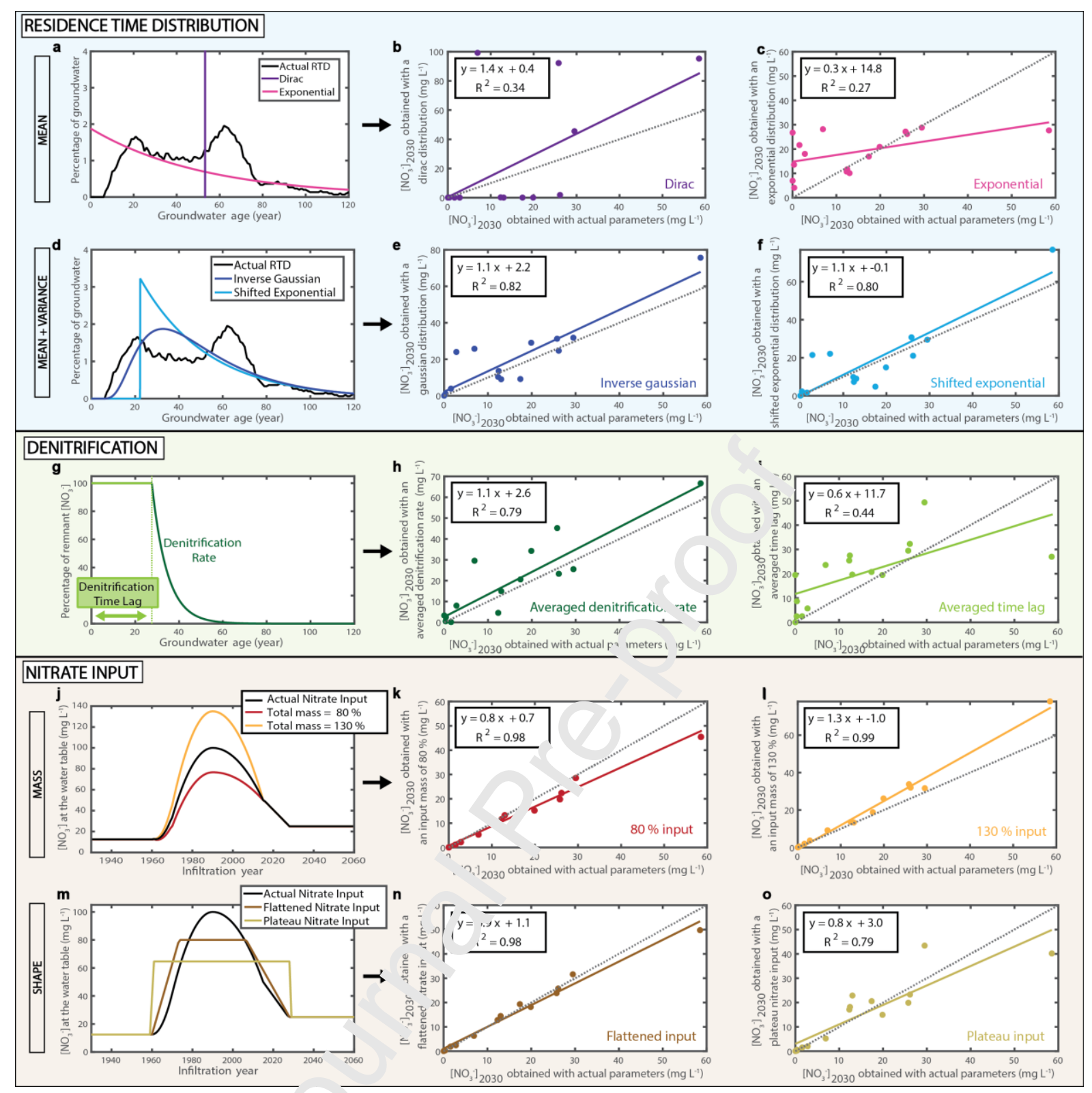


Figure 2. Results of the sensitivity analysis were performed according to the reference model including the references for the residence time distribution, denitrification rate and duration, and nitrogen inputs. Subplots on the left illustrate the parameters and functions tested. For the 10 other subplots, on the middle and on the right, the nitrate concentration predicted for 2030 with the reference model is represented on the $\mathrm{x}$-axis, while the $\mathrm{y}$-axis represents the nitrate concentration predicted for 2030 with one modified parameter. Each dot corresponds to a well. Solid lines come from linear regressions and are described by the equation and associated $\mathrm{R}^{2}$ coefficients in the top right frame. The $1: 1$ trend is ¿'splayed by a dashed line. Basically, the closer the regression line is to the dashed lire a d the smaller the dispersion is, the less the predictions are sensitive to the parameter te ${ }^{+}{ }^{+}$. Note that the analysis is only weakly sensitive to any of the wells even though sr mu noints look like outliers as the well with the highest concentration on Figures $\left.2 c c_{a}\right)$, where more than half of the other nitrate concentrations are significantly overprec $-\mathrm{t} r \mathrm{~d}$. 


\subsubsection{Sensitivity to residence time distribution}

The sensitivity analysis revealed that the mean residence time was insufficient on its own to make predictions of future nitrate concentration (Figure 2 a-c). A Dirac distribution, corresponding to a piston-flow model where the age of the whole water mass is equal to the mean residence time, created a binary response, where denitrification occurred either on all flow lines or not at all (Figure 2 b). Alternatively, an exponential distribution, corresponding to well-mixed flows, led to a homogenization of the nitrate concentration towards intermediate values that did not reflect the spatial heterogenei ${ }^{+}{ }_{\mathrm{f}} \mathrm{f}$ lite catchment (Figure $2 \mathrm{c}$ ). Nitrate concentrations are strongly overestimated for alr ost half of the wells. For both 1parameter LPMs, the correlation coefficient of the linear regression between the concentrations predicted by the reference model and he concentration predicted by the modified model is lower than 0.35 (Figr e 2 b-c). Thus, despite their convenience, 1-parameter LPMs have very poor predic ${ }^{\top}$ e capacities of nitrate concentrations.

Integrating information of both li. mean and standard deviation of the residence time distribution allowed reasonable p.dicion of future nitrate concentration. Indeed, predictions obtained with the 2-parameters I,PMs (Inverse Gaussian, Shifted exponential, Gamma and Uniform models) shower hew agreement with the reference predictions (Figure 2 e-f and Figure $\mathrm{S} 2)$. The slopes,$f$ the regression lines were close to $1(\sim 1.1)$, their intercepts were lower than 3 , and the associated correlation coefficients $\left(\mathrm{R}^{2}\right)$ were above 0.8 .

\subsubsection{Sensitivity to denitrification}

To predict future nitrate concentration, it mattered more to know the time needed for the denitrification to start, $t_{l a g}$, than the precise rate of the denitrification once it began, $\tau_{N O 3}$ (Figure 2 g-i). Indeed, replacing actual denitrification rates $\tau_{N O 3}$ by the average denitrification rate of the catchment did not bias significantly the predictions of future nitrate concentration (Figure $2 \mathrm{~h}$ ). The slope of the regression line between the concentration predicted using 
actual parameters and the concentration predicted using an average denitrification rate was close to 1 (1.1), and the intercept value was low (2.6), showing little systematic bias. On the contrary, replacing actual denitrification time lags $t_{\text {lag }}$ by the average time lag over the 16 wells significantly biased the predictions of future nitrate concentrations (Figure 2 i). Most of the nitrate concentrations are overpredicted. We thus conclude that, in the saturated zone of the investigated aquifer, the nitrate concentration appears to be primarily controlled by the time needed for the denitrification to start, which is much longer than the actual time of reaction. This suggests that denitrification can virtually be corride. $2 d$ as an ON/OFF system, in which the important point to set is whether it has begun or 1 . tt.

\subsubsection{Sensitivity to the past nitrogen inputs}

As expected, the total mass of nitrate th" : enterea the aquifer since the beginning of the industrial period impacted the absolnte alues of the output nitrate concentration in groundwater (Figure $2 \mathrm{k}-1$ ). A change in the input mass had a proportional effect on the aquifer concentration predictions. $N^{\circ} \cdot$ surprisingly, uncertainties in the shape of the nitrate input time series did not subst.untın'ly bias predictions (Figure $2 \mathrm{~m}-\mathrm{o}$ ). If the peak was flattened to a plateau that las $2 \mathrm{c}$ years, the output concentration remained very close to the actual concentration, wit 1 a lope of 0.9 and an $\mathrm{R}^{2}$ of 0.98 . If the time series was simplified to the extreme (i.e. a uniqu plateau lasting from the beginning of the industrial period to the return to a stable concentration), the predicted concentration was still relatively close to actual concentration, with a slope of 0.8 and a $R^{2}$ of 0.79 . Thus, a first-order reconstruction of the nitrate input time series, based only on the starting time of input and the total mass of nitrate that entered the aquifer, already yielded reasonable predictions of nitrate concentrations in groundwater (Figure 2 n). If an additional evaluation of the period during which the input concentration reached its maximum was made, then, the predictions became very accurate (Figure $2 \mathrm{o}$ ). The low sensitivity to the shape of the input time series can be 
explained from the natural mixing of groundwater flow lines, which spreads the residence time distributions and flattens the nitrate time series.

\section{Discussion}

\subsection{Local hydrogeomorphic and biogeochemical conditions induce a high variability on nitrate concentrations}

The nitrate input reduction scenarios revealed large local variatı? 2 in groundwater's nitrate concentration response despite identical initial input. In sc no vi the wells, 5 to 15 years after a sudden stop of the nitrogen inputs, groundwater pollui nn was still almost as high as if the input had not decreased (Figure 1). However, in the ame $35 \mathrm{~km}^{2}$ catchment, other wells showed a nitrate concentration close to $0 \mathrm{mg} / \mathrm{T}$, , ve a in the worse input scenario (Figure 1 ). This underlines how strongly the $\mathrm{m}$ r l-scale variability of hydrogeomorphic and biogeochemical conditions affect nitra ${ }^{+}$, concentrations in fractured-bedrock aquifers. More generally, the observed water quality st tte and recovery rate for a given catchment depends on both the degree of nutrient oaaing and the overall retention and removal capacity, which can vary substantially in bo : su face and subsurface environments (Cheng et al. 2020; Frei et al. 2020) .

The time lag of measurable impacts of nitrate input mitigation strategies depends on local groundwater flowpaths. Hence, there is an urge to be able to characterize both local heterogeneity and the time lag of the response of aquifers to restoration measures to set realistic management targets (Dupas et al. 2018). Indeed, no clear decrease in nitrate concentrations after several years of stringent mitigation efforts could simply indicate that improvements have not yet propagated through the system (Sebilo et al. 2013). A lack of consideration of these time lags could discourage farmers and politicians and could provoke 
fines and penalties for nonattainment of water quality goals despite real progress if they were set on an unrealistic time scale (Meals et al. 2010).

\subsection{Residence times: a single age tracer is not enough}

In many studies, the residence time distribution is constrained by natural tracers (Ayraud et al. 2008; Böhlke and Denver 1995; Visser et al. 2013). Here we found that both the mean and the standard deviation of the groundwater residence time distribution were necessary, and sufficient, to make predictions of future nitra! concentrations (Figure 2). Thus, a single age tracer, giving a single apparent age, does $1.7 t \cdot$.low adequate prediction of future groundwater nitrate concentration. The distribut in siould not be reduced to a Dirac distribution where the only parameter would be $a_{\imath}^{\prime}$ 'n', ther the mean and apparent ages. Therefore, accurate predictions require to cons $r .1$ the standard deviation of the residence time distribution either by measuring a 1 a ldilional age tracer, or by using a model. Our finding is consistent with Marcais $c^{+}$al. (2v15), who used results from groundwater flow models to show that two indepenc e't uge tracers interpreted with a priori relevant LPM models are enough to constrair kı: quantiles of the residence time distribution. It also agrees with Eberts et al. (2012), v'ho 1 und evidence that lumped parameter models calibrated with two or three age ti ces $c$ in be as efficient as particle tracking models to assess the vulnerability of wells to _ontamination.

Measuring the first two moments (mean and standard deviation) of the RTD requires two independent age tracers, which is often challenging. One way to circumvent the problem could be found in recent studies that demonstrate the linkage between geology, topography and residence times (McGuire et al. 2005; Soulsby and Tetzlaff 2008; Starn and Belitz 2018; Tetzlaff et al. 2009). Correlating the mean age and the variability of RTD with geomorphological characteristics, such as the total volume and the heterogeneity of the aquifer, is increasingly investigated on the basis of local to regional groundwater flow and 
transport models (Starn et al., 2021; Gauvain et al., 2021). Simulation results are handled either to determine generic rules or as an input to machine learning algorithms to eventually upscale residence times and nitrate predictions on the basis of widely available geological and topographic data.

\subsection{Denitrification: the time to start is more important than the}

\section{reaction rate}

When considering denitrification, it is essential to distingui h the time needed for the reaction to start from the time needed for the reaction its - Il Kolbe et al., 2019). Our study confirmed that the denitrification time lag is the primary control of nitrate concentration in groundwater, rather than variation in denitrification ial itself (Figure 2). Once $\mathrm{O}_{2}$ has been sufficiently depleted, nitrate reduction is very $t_{n}$ ct jompared to the denitrification time lag. The characteristic denitrification time is . hu, only a secondary control.

Oxygen and nitrate reduction equire the availability of electron donors (Korom 1992), typically organic matter on ny i.e (Hosono et al. 2013; Pauwels et al. 2000). In our system, organic carbon is mos ${ }^{1} \mathrm{y}$ consumed in the soil and is not abundant in the saturated zone of the aquifer. Thus in he aquifer, oxygen and nitrate degradation depend on the availability of mineral c'actron donors such as pyrite (Bochet et al. 2020). Kolbe et al. (2019) proposed a conceptual framework in which the aquifer is divided into a shallow, non-reactive zone that lacks available electron donors, and a deep, reactive zone, with available electron donors. After leaching from the soil, the groundwater first flows through the non-reactive zone, where neither $\mathrm{O}_{2}$ nor $\mathrm{NO}_{3}{ }^{-}$is degraded. As soon as the groundwater enters the deep reactive zone, where electron donors are again available, $\mathrm{O}_{2}$ is quickly consumed, followed by $\mathrm{NO}_{3}{ }^{-}$. Thus, the denitrification time lag is mainly controlled by the time needed for the nitrate to reach the reactive zone of the aquifer. This framework is consistent with piezometer 
profiles established by Postma et al. (1991) in an unconfined sandy aquifer, showing that oxygen and nitrate concentrations suddenly decrease at a depth that coincides with the apparition of pyrite. Kolbe et al. (2019) additionally correlated the depth of the reactive zone with the thickness of the geologically weathered zone. They proposed that geological weathering alters reduced minerals, inducing a stratification of biogeochemical activity.

Results from Böhlke and Denver (1995) in a well-instrumented sedimentary aquifer also suggested a stratification of denitrification related to the stratification of sedimentary layers. Our results, combined with the concept of stratified macivity, suggest that the key parameter of denitrification could be characterized bas ea nn weathering profiles of the aquifer. Such profiles can be obtained by geophysical $\eta_{1}$ 'specting such as seismic imaging (Holbrook et al. 2014; Parsekian et al. 2015; Pasquet at a' 2015; St. Clair et al. 2015).

\subsection{The interplay between ras. tence times and denitrification}

\section{controls nitrate concertration}

Finally, the nitrate concentanti $n$ in the aquifer is controlled by the proportion of water younger than the denitrificatic. time lag (Figure 3). This young water did not encounter the reactive zone at all, meaning th at it has the same nitrate concentration as the saturated zone input. Groundwater oli'r than the denitrification time lag is almost fully denitrified and contains a very small amount of $\mathrm{NO}_{3}{ }^{-}$. Because the denitrification time lag is directly related to the time needed for oxygen to be consumed, $\mathrm{O}_{2}$ concentration could be used as a proxy for the proportion of water younger than the denitrification time lag. Our results support Green et al. (2016), who proposed to use $\mathrm{O}_{2}$ measurements to characterize denitrification processes. $\mathrm{O}_{2}$ can be cheaply and reliably measured via routine laboratory and field methods, though care must be taken to avoid reaeration or degassing during sampling. Using groundwater oxygen concentration would greatly increase our capacity to predict nitrate removal at large scales. 
The interplay between residence times and denitrification can be illustrated by looking at the $\mathrm{NO}_{3}{ }^{-}$trajectories in three wells with very distinctive flows and reactive conditions of the aquifer (Figure 3). The well that contains the largest fraction of water younger than the time needed for denitrification to start $\left(t_{\text {lag }}\right)$ displays the highest $\mathrm{NO}_{3}{ }^{-}$concentration (well 1 ). The presence of very short flowpaths also leads to a rapid response to agricultural changes and allows the difference between the three input scenarios to be seen immediately. In the well with a smaller amount of water younger than $t_{\text {lag }}$, the $\mathrm{NO}_{3}{ }^{-}$concentration is lower (well 2). However, the absence of very short flowpaths delar th response to nitrate input decrease scenarios. For more than 10 years after a ban $\mathrm{c}_{1} \mathrm{in}$ +rogen input, the concentration remained as if no change had been made. In the last well, the combination of a short denitrification time lag and the absence of very jou.' flowpaths leads to a zero $\mathrm{NO}_{3}{ }^{-}$ concentration, because only denitrified flow ja is ieach the well (well 3). Since the whole water mass is older than the denitrific. tir 1 time lag, this well is not vulnerable to $\mathrm{NO}_{3}{ }^{-}$ pollution and its concentration is insunsitive to any other parameter. These case studies highlight that the $\mathrm{NO}_{3}{ }^{-}$trajectorier arc soverned by the fraction of groundwater younger than the denitrification time lag. Thi fraction is defined by the interplay between the mean and the standard deviation of the res:dince time distribution, and the denitrification time lag. The heterogeneity of these 'rey parameters induces a spatially variable vulnerability to $\mathrm{NO}_{3}{ }^{-}$ pollution over the aquifer. 


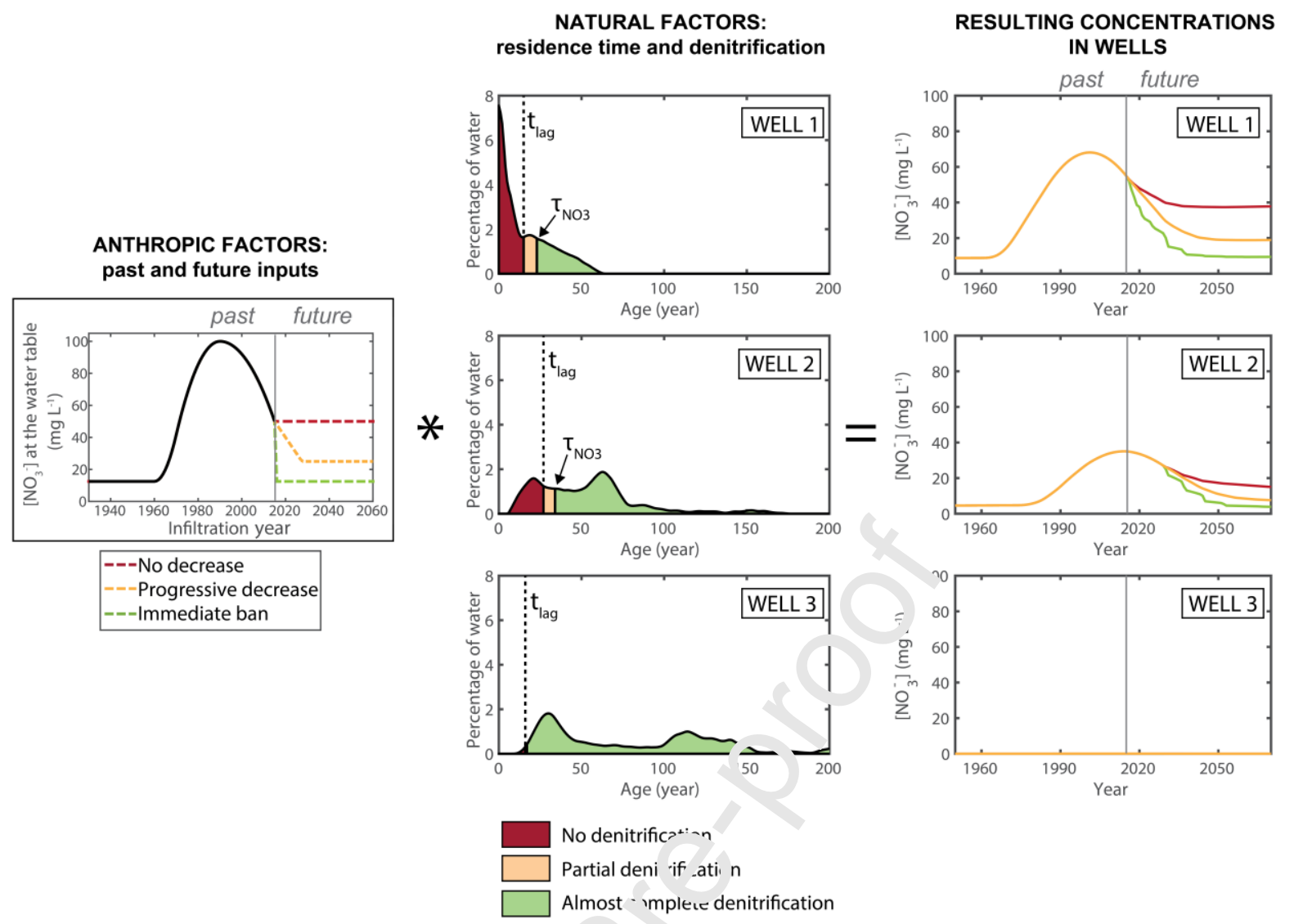

Figure 3. Prediction of the nitrate traject ies in three wells, following the three scenarios presented in section 2.2.3. The $\mathrm{NO}_{3}{ }^{-}$co. entration in the wells (on the right panels) results from the convolution of the anthr $\mathrm{s}$ i- ractors (on the left panel) and the natural factors (on the middle panels). The natural fach ${ }^{\text {rs }}$ are themselves a combination of hydrogeology (residence time distribution) and rive eunemistry (denitrification). The denitrification time lag, $t_{\text {lag }}$, (dashed line) and the ch racteristic reaction time, $\tau_{\mathrm{NO} 3}$ (arrow) are indicated in the middle pannels.

\subsection{Nitrate inputs: uncertainty about the past does not hamper}

\section{predictions of the future}

Reconstructing nitrate input time series requires substantial resources and presents multiple challenges (Oenema et al. 2003; Payraudeau et al. 2007; Poisvert et al. 2016; Salo and Turtola 2006). Our study shows that in catchments without available nitrate input time 
series, a simplified time series allows reasonable estimations of future nitrate concentration in groundwater. Although the total mass of nitrate that entered the system since the beginning of the industrial period has to be estimated, the shape of the time series does not substantially affect predictions (Figure 2). Indeed, natural mixing of young and old groundwater smooths the nitrogen input time series in the aquifer (McDonnell et al. 2010). Regarding the state of current knowledge and the sensitivity of nitrate concentrations, it seems that larger gaps remain in the characterization of natural parameters of the groundwater system than on the reconstruction of the nitrate input time series.

\section{Conclusion}

Based on a calibrated model, we predicted th n. *ate trajectories in 16 wells (28 to 98 $\mathrm{m}$ deep) of an unconfined fractured bedrock ar, $\mathrm{u}_{1}{ }^{\prime} \mathbf{r}$, ocated in an agricultural area of Western France. Groundwater flow in the satura $d$ one was responsible for a marked nitrate legacy, delaying for several years the impact of mitigation strategies in some parts of the catchment. This highlights the need to determine were and when the results of mitigation efforts have a chance to be measurable. A sensitivity analysis on the predicted nitrate concentrations showed that the nitrate concent ation in the aquifer can be predicted using a limited number of parameters:

1. the total mass of nitrate that entered the saturated zone in the past, which can be estimated with land use data.

2. the mean and the variance of the groundwater residence time distribution, which can be measured with a minimum of two age tracers. If only one age tracer is available, it must be combined with a model or an assumption on the residence time variance, that could be based on geomorphologic analysis. 
3. the time needed for the groundwater to reach the reactive zone of the aquifer, which can be evaluated with groundwater dissolved oxygen concentration.

Other parameters, especially the precise shape of the nitrate input time series, have little impact on the recovery trajectory of the aquifer. At this point, we are able to evaluate these key parameters at a local scale, appropriate for policy implementations. Even if the path forward to upscale these parameters remains unclear, determining what information is most needed and valuable is the first step towards large scale predictions. The fact that the groundwater nitrate trajectories can be approached with a limi+^d n nowledge of the system is promising regarding our future ability to predict nitrate co’ ‘aı ' ination of groundwater.

\section{References}

Abbott, B. W., V. Baranov, C. Mendoza 'e a, M. Nikolakopoulou, A. Harjung, T. Kolbe, M. N. Balasubramanian, T. N. Viessen, F. Ciocca, A. Campeau, M. B. Wallin, P. Romeijn, M. Antonelli, J. Fo1. ^ilves, T. Datry, A. M. Laverman, J.-R. de Dreuzy, D. M. Hannah, S. Krause, T. Gidham \& G. Pinay, 2016. Using multi-tracer inference to move beyond sinole $\cdots$.tchment ecohydrology. Earth-Science Reviews 160:19-42 doi:10.1016/j.eia `cirev.2016.06.014.

Abbott, B. W., K. Bishop, J. P. Zarnetske, C. Minaudo, F. S. Chapin, S. Krause, D. M. Hannah, L. Conner, D. Ellison, S. E. Godsey, S. Plont, J. Marçais, T. Kolbe, A. Huebner, R. J. Frei, T. Hampton, S. Gu, M. Buhman, S. Sara Sayedi, O. Ursache, M. Chapin, K. D. Henderson \& G. Pinay, 2019. Human domination of the global water cycle absent from depictions and perceptions. Nature Geoscience 12(7):533-540 doi:10.1038/s41561-019-0374-y. 
Abbott, B. W., F. Moatar, O. Gauthier, O. Fovet, V. Antoine \& O. Ragueneau, 2018. Trends and seasonality of river nutrients in agricultural catchments: 18years of weekly citizen science in France. The Science of the total environment 624:845-858 doi:10.1016/j.scitotenv.2017.12.176.

Aeschbach-Hertig, W., F. Peeters, U. Beyerle \& R. Kipfer, 1999. Interpretation of dissolved atmospheric noble gases in natural waters. Water Resources Research 35(9):27792792 doi:10.1029/1999wr900130.

Aquilina, L., V. Vergnaud-Ayraud, T. Labasque, O. Bour, I. Molenat, L. Ruiz, V. de Montety, J. De Ridder, C. Roques \& L. Longue e $_{z}$ ne, 2012. Nitrate dynamics in agricultural catchments deduced from groundw.ter dating and long-term nitrate monitoring in surface- and groundwaters. $\mathrm{Tr}$ e $\mathrm{s}$-ience of the total environment 435436:167-78 doi:10.1016/j.scitotenv.20’2.‘' 's28.

Ayraud, V., L. Aquilina, T. Labasque, I. P.uwels, J. Molenat, A.-C. Pierson-Wickmann, V. Durand, O. Bour, C. Tarits, r. Le Corre, E. Fourre, P. Merot \& P. Davy, 2008.

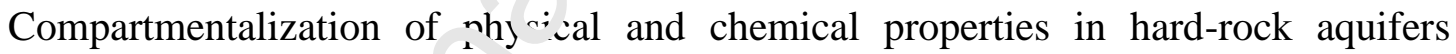
deduced from chemic.1 and groundwater age analyses. Applied Geochemistry

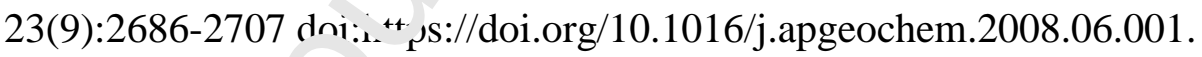

Barbe, L., A. Prinzing, . . Mony, B. Abbott, M. Santonja, K. Hoeffner, S. Guillocheau, D. Cluzeau, A. J. Francez, N. Bris \& V. Jung, 2019. Opposing Effects of PlantCommunity Assembly Maintain Constant Litter Decomposition over Grasslands Aged from 1 to 25 Years. Ecosystems:1-13 doi:10.1007/s10021-019-00392-8.

Bernard-Griffiths, J., J. J. Peucat, S. Sheppard \& P. Vidal, 1985. Petrogenesis of Hercynian leucogranites from the southern Armorican Massif: contribution of REE and isotopic $(\mathrm{Sr}, \mathrm{Nd}, \mathrm{Pb}$ and $\mathrm{O})$ geochemical data to the study of source rock characteristics and 
ages. Earth and Planetary Science Letters 74(2):235-250 doi:https://doi.org/10.1016/0012-821X(85)90024-X.

Bochet, O., L. Bethencourt, A. Dufresne, J. Farasin, M. Pédrot, T. Labasque, E. Chatton, N. Lavenant, C. Petton, B. W. Abbott, L. Aquilina \& T. Le Borgne, 2020. Iron-oxidizer hotspots formed by intermittent oxic-anoxic fluid mixing in fractured rocks. Nature Geoscience 13(2):149-155 doi:10.1038/s41561-019-0509-1.

Boers, P. C. M., 1996. Nutrient emissions from agriculture in the Netherlands, causes and remedies. Water Science and Terhnoingy 33(4-5):183-189 doi:10.2166/wst.1996.0503.

Böhlke, J. K. \& J. M. Denver, 1995. Combined Use of Čroundwater Dating, Chemical, and Isotopic Analyses to Resolve the History an 1 rite of Nitrate Contamination in Two Agricultural Watersheds, Atlantic Co. st.d Plain, Maryland. Water Resources Research 31(9):2319-2339 doi:d` $\because \cdot 1 ' J .1029 / 95 W R 01584$.

Busenberg, E. \& L. N. Plummer, 19y? Use of chlorofluorocarbons (ccl3f and ccl2f2) as hydrologic tracers and ag da $^{i}$ ing tools - the alluvium and terrace system of central oklahoma. Water Resoı “ces Research 28(9):2257-2283 doi:10.1029/92wr01263.

Cheng, F. Y., K. J. Van Me ^r, D. K. Byrnes \& N. B. Basu, 2020. Maximizing US nitrate removal throug: wetland protection and restoration. Nature 588(7839):625-630 doi:10.1038/s41586-020-03042-5.

Choi, B. C., T. Pang, V. Lin, P. Puska, G. Sherman, M. Goddard, M. J. Ackland, P. Sainsbury, S. Stachenko, H. Morrison \& C. Clottey, 2005. Can scientists and policy makers work together? J Epidemiol Community Health 59(8):632-7 doi:10.1136/jech.2004.031765.

Diersch, H. J. G., 2013. FEFLOW-Finite Element Modeling of Flow, Mass and Heat Transport in Porous and Fractured Media. Springer Science \& Business Media. 
Dupas, R., C. Minaudo, G. Gruau, L. Ruiz \& C. Gascuel-Odoux, 2018. Multidecadal Trajectory of Riverine Nitrogen and Phosphorus Dynamics in Rural Catchments. Water Resources Research 54(8):5327-5340 doi:10.1029/2018wr022905.

Eberts, S. M., J. K. Böhlke, L. J. Kauffman \& B. C. Jurgens, 2012. Comparison of particletracking and lumped-parameter age-distribution models for evaluating vulnerability of production wells to contamination. Hydrogeology Journal 20(2):263-282 doi:10.1007/s10040-011-0810-6.

Ehrhardt, S., R. Kumar, J. H. Fleckenstein, S. Attinger \& A Mus >lff, 2019. Trajectories of nitrate input and output in three nested catchr ıen s along a land use gradient. Hydrology and Earth System Sciences 23(9)·25`3-3524 doi:10.5194/hess-23-35032019.

Engdahl, N. B. \& R. M. Maxwell, 2014. App os m ^ting groundwater age distributions using simple streamtube models and $n .1 t:$ ple tracers. Advances in Water Resources 66:1931 doi:https://doi.org/10.1016/... Jvwatres.2014.02.001.

Fenton, O., R. P. O. Schulte, P. I $\neg$ dı ^, S. T. J. Lalor \& K. G. Richards, 2011. Time lag: a methodology for the stiniation of vertical and horizontal travel and flushing timescales to nitrate li. shold concentrations in Irish aquifers. Environmental Science \& Policy 14(4):-'1y-431 doi:https://doi.org/10.1016/j.envsci.2011.03.006.

Frei, R. J., B. W. Abbott, R. Dupas, S. Gu, G. Gruau, Z. Thomas, T. Kolbe, L. Aquilina, T. Labasque, A. Laverman, O. Fovet, F. Moatar \& G. Pinay, 2020. Predicting Nutrient Incontinence in the Anthropocene at Watershed Scales. Frontiers in Environmental Science 7 doi:10.3389/fenvs.2019.00200.

Galloway, J. N., A. R. Townsend, J. W. Erisman, M. Bekunda, Z. Cai, J. R. Freney, L. A. Martinelli, S. P. Seitzinger \& M. A. Sutton, 2008. Transformation of the Nitrogen 
Cycle: Recent Trends, Questions, and Potential Solutions. Science 320(5878):889-892 doi:10.1126/science.1136674.

Ginn, T. R., 1999. On the distribution of multicomponent mixtures over generalized exposure time in subsurface flow and reactive transport: Foundations, and formulations for groundwater age, chemical heterogeneity, and biodegradation. Water Resources Research 35(5):1395-1407 doi:10.1029/1999wr900013.

Green, C. T., B. C. Jurgens, Y. Zhang, J. J. Starn, M. J. Singleton \& B. K. Esser, 2016. Regional oxygen reduction and denitrification rates in ${ }_{0}^{-r o u}$. dwater from multi-model residence time distributions, San Joaquin Val' $-\mathrm{y}$, USA. Journal of Hydrology 543:155-166 doi:10.1016/j.jhydrol.2016.05.01

Hamilton, S. K., 2012. Biogeochemical time las, 1. ay delay responses of streams to ecological restoration. Freshwate R:ology 57:43-57 doi:10.1111/j.13652427.2011.02685.x.

Holbrook, S., C. S. Riebe, M. Elwaseı, J. Hayes, K. Basler-Reeder, D. Harry, A. Malazian, A. Dosseto, P. Hartsougr \& I. Hopmans, 2014. Geophysical constraints on deep weathering and wate storage potential in the Southern Sierra Critical Zone

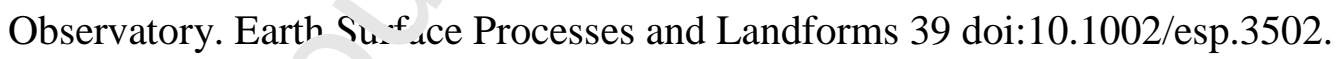

Hosono, T., T. Tokuna $a_{i}^{-}$, M. Kagabu, H. Nakata, T. Orishikida, I. T. Lin \& J. Shimada, 2013. The use of delta $15 \mathrm{~N}$ and delta180 tracers with an understanding of groundwater flow dynamics for evaluating the origins and attenuation mechanisms of nitrate pollution. Water Res 47(8):2661-75 doi:10.1016/j.watres.2013.02.020.

Hrachowitz, M., O. Fovet, L. Ruiz \& H. H. G. Savenije, 2015. Transit time distributions, legacy contamination and variability in biogeochemical 1/f $\alpha$ scaling: how are hydrological response dynamics linked to water quality at the catchment scale? Hydrological Processes 29(25):5241-5256 doi:10.1002/hyp.10546. 
Kolbe, T., J. R. de Dreuzy, B. W. Abbott, L. Aquilina, T. Babey, C. T. Green, J. H. Fleckenstein, T. Labasque, A. M. Laverman, J. Marcais, S. Peiffer, Z. Thomas \& G. Pinay, 2019. Stratification of reactivity determines nitrate removal in groundwater. Proc Natl Acad Sci U S A 116(7):2494-2499 doi:10.1073/pnas.1816892116.

Kolbe, T., J. Marçais, Z. Thomas, B. W. Abbott, J.-R. de Dreuzy, P. Rousseau-Gueutin, L. Aquilina, T. Labasque \& G. Pinay, 2016. Coupling 3D groundwater modeling with CFC-based age dating to classify local groundwater circulation in an unconfined $\begin{array}{llll}\text { crystalline } & \text { aquifer. Journal of } & \text { h } \text { jdrology } & \text { of } 31-46\end{array}$ doi:https://doi.org/10.1016/j.jhydrol.2016.05.020.

Korom, S. F., 1992. Natural denitrification in the saturate. zone: A review. Water Resources Research 28(6):1657-1668 doi:10.1029/92wr $30_{\llcorner} \leq 2$.

Kronvang, B., H. E. Andersen, C. Børgesen, T. ) gaard, S. E. Larsen, J. Bøgestrand \& G. Blicher-Mathiasen, 2008. Effec . c. policy measures implemented in Denmark on nitrogen pollution of the aquatic environment. Environmental Science \& Policy 11(2):144-152 doi:10.1016'i.e. 'sci.2007.10.007.

Kronvang, B., E. Jeppesen, D. I. Conley, M. Søndergaard, S. E. Larsen, N. B. Ovesen \& J. Carstensen, $2005 \mathrm{~N}_{\iota^{+}}{ }^{*}$ ent pressures and ecological responses to nutrient loading reductions in La`isı streams, lakes and coastal waters. Journal of Hydrology 304(14):274-288 doi:10.1016/j.jhydrol.2004.07.035.

Le Moal, M., C. Gascuel-Odoux, A. Menesguen, Y. Souchon, C. Etrillard, A. Levain, F. Moatar, A. Pannard, P. Souchu, A. Lefebvre \& G. Pinay, 2019. Eutrophication: A new wine in an old bottle? The Science of the total environment 651(Pt 1):1-11 doi:10.1016/j.scitotenv.2018.09.139.

Le Moigne, P., 2009. SURFEX scientific documentation. 87:211. 
Leray, S., N. B. Engdahl, A. Massoudieh, E. Bresciani \& J. McCallum, 2016. Residence time distributions for hydrologic systems: Mechanistic foundations and steady-state $\begin{array}{llll}\text { analytical } & \text { solutions. Journal of Hydrology }\end{array}$ doi:10.1016/j.jhydrol.2016.01.068.

Maloszewski, P. \& A. Zuber, 1996. Lumped parameter models for the interpretation of environmental tracer data. International Atomic Energy Agency (IAEA), 9-58.

Małoszewski, P. \& A. Zuber, 1982. Determining the turnover time of groundwater systems with the aid of environmental tracers: 1 . Models and thei- applicability. Journal of

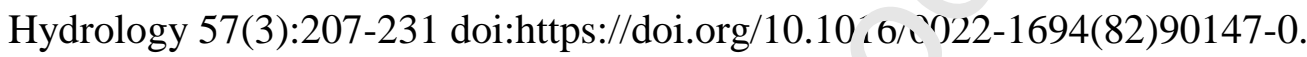

Marcais, J., J. R. de Dreuzy, T. R. Ginn, P. Rousseaי-L 'eutin \& S. Leray, 2015. Inferring transit time distributions from atmospheric $t$ ac ${ }^{-}$data: Assessment of the predictive capacities of Lumped Parameter Mode`s , $n, 3$ D crystalline aquifer model. Journal of Hydrology 525:619-631 doi:10.i ‘1f,j.jhydrol.2015.03.055.

Marcais, J., A. Gauvain, T. Labasque, ?. W. Abbott, G. Pinay, L. Aquilina, F. Chabaux, D. Viville \& J. R. de Dreuzy, ? ${ }^{15}$. Dating groundwater with dissolved silica and CFC concentrations in crysta' 'line aquifers. The Science of the total environment 636:260272 doi:10.1016/j crıネ゙,nv.2018.04.196.

McDonnell, J. J., K. M.`(suire, P. Aggarwal, K. J. Beven, D. Biondi, G. Destouni, S. Dunn, A. James, J. Kirchner, P. Kraft, S. Lyon, P. Maloszewski, B. Newman, L. Pfister, A. Rinaldo, A. Rodhe, T. Sayama, J. Seibert, K. Solomon, C. Soulsby, M. Stewart, D. Tetzlaff, C. Tobin, P. Troch, M. Weiler, A. Western, A. Wörman \& S. Wrede, 2010. How old is streamwater? Open questions in catchment transit time conceptualization, modelling and analysis. Hydrological Processes 24(12):1745-1754 doi:10.1002/hyp.7796. 
McDonnell, J. J., M. Sivapalan, K. Vache, S. Dunn, G. Grant, R. Haggerty, C. Hinz, R. Hooper, J. Kirchner, M. L. Roderick, J. Selker \& M. Weiler, 2007. Moving beyond heterogeneity and process complexity: A new vision for watershed hydrology. Water Resources Research 43(7) doi:10.1029/2006wr005467.

McGuire, K. J., J. J. McDonnell, M. Weiler, C. Kendall, B. L. McGlynn, J. M. Welker \& J. Seibert, 2005. The role of topography on catchment-scale water residence time. Water Resources Research 41(5) doi:10.1029/2004wr003657.

Meals, D. W., S. A. Dressing \& T. E. Davenport, 2010. Lag Time in Water Quality Response to Best Management Practices: A Review , Environ Qual 39(1):85-96 doi:10.2134/jeq2009.0108.

Minaudo, C., R. Dupas, C. Gascuel-Odoux, V. Rc abc x, P.-A. Danis \& F. Moatar, 2019. Seasonal and event-based concentratic a- 1 er narge relationships to identify catchment controls on nutrient export re, imes. Advances in Water Resources 131 doi:10.1016/j.advwatres.2019.1`3379.

Noilhan, J. \& J. F. Mahfouf, 1996 T. ISBA land surface parameterisation scheme. Global and Planetary C.ange 13(1):145-159 doi:https://doi.org/10.1016/09218181(95)00043-7.

Oenema, O., H. Kros \& W. de Vries, 2003. Approaches and uncertainties in nutrient budgets: implications for nutrient management and environmental policies. European Journal of Agronomy 20(1-2):3-16 doi:10.1016/s1161-0301(03)00067-4.

Paradis, D., J.-M. Ballard, R. Lefebvre \& M. M. Savard, 2017. Multi-scale nitrate transport in a sandstone aquifer system under intensive agriculture. Hydrogeology Journal 26(2):511-531 doi:10.1007/s10040-017-1668-z. 
Parris, K., 1998. Agricultural nutrient balances as agri-environmental indicators: an OECD perspective. Environmental Pollution 102(1, Supplement 1):219-225 doi:https://doi.org/10.1016/S0269-7491(98)80036-5.

Parsekian, A. D., K. Singha, B. J. Minsley, W. S. Holbrook \& L. Slater, 2015. Multiscale geophysical imaging of the critical zone. Rev Geophys 53(1):1-26 doi:10.1002/2014rg000465.

Pasquet, S., L. Bodet, L. Longuevergne, A. Dhemaied, C. Camerlynck, F. Rejiba \& R. Guérin, 2015. 2D characterization of near-surface VD/VD. Surface-wave dispersion inversion versus refraction tomography. "vea. Surface Geophysics 13 doi:10.3997/1873-0604.2015028.

Pauwels, H., J.-C. Foucher \& W. Kloppmann, 200\%. L'nitrification and mixing in a schist aquifer: influence on water chemistry a.d sotopes. Chemical Geology 168(3):307324 doi:https://doi.org/10.1016/S ग) গ-2541(00)00201-1.

Payraudeau, S., H. M. G. van der h $\operatorname{rrf} \&$ F. Vertès, 2007. Analysis of the uncertainty associated with the estim ${ }^{+i}$ or $r_{i}$ nitrogen losses from farming systems. Agricultural Systems 94(2):416-43C toi:10.1016/j.agsy.2006.11.014.

Pinay, G., S. Peiffer, J. R \e Dreuzy, S. Krause, D. M. Hannah, J. H. Fleckenstein, M. Sebilo, K. Bish $n$ \& L. Hubert-Moy, 2015. Upscaling Nitrogen Removal Capacity from Local Hotspots to Low Stream Orders' Drainage Basins. Ecosystems 18(6):1101-1120 doi:10.1007/s10021-015-9878-5.

Poisvert, C., F. Curie \& F. Moatar, 2016. Annual agricultural N surplus in France over a 70year period. Nutrient Cycling in Agroecosystems 107(1):63-78 doi:10.1007/s10705016-9814-x. 
Postma, D., C. Boesen, H. Kristiansen \& F. Larsen, 1991. Nitrate Reduction in an Unconfined Sandy Aquifer: Water Chemistry, Reduction Processes, and Geochemical Modeling. Water Resources Research 27(8):2027-2045 doi:10.1029/91wr00989.

Salo, T. \& E. Turtola, 2006. Nitrogen balance as an indicator of nitrogen leaching in Finland. Agriculture, $\quad$ Ecosystems $\quad \& \quad$ Environment $\quad 113(1-4): 98-107$ doi:10.1016/j.agee.2005.09.002.

Sebilo, M., B. Mayer, B. Nicolardot, G. Pinay \& A. Mariotti, 2013. Long-term fate of nitrate fertilizer in agricultural soils. Proc Natl Acad S^i it S A 110(45):18185-9 doi:10.1073/pnas.1305372110.

Singleton, M. J., B. K. Esser, J. E. Moran, G. B. Hudınn, W. W. McNab \& T. Harter, 2007. Saturated Zone Denitrification: Potential tu- Natural Attenuation of Nitrate Contamination in Shallow Groundv at $r$ Jnder Dairy Operations. Environ Sci Technol 41(3):759-765 doi:10.1C?1/‘s061253g.

Soulsby, C. \& D. Tetzlaff, 2008. Tuvards simple approaches for mean residence time estimation in ungauged has. $n$, using tracers and soil distributions. Journal of Hydrology 363(1-4):6C 74 doi:10.1016/j.jhydrol.2008.10.001.

St. Clair, J., S. Moon, W J. 'olbrook, J. T. Perron, C. S. Riebe, S. J. Martel, B. Carr, C. Harman, K. Sincha \& D. d. Richter, 2015. Geophysical imaging reveals topographic stress control of bedrock weathering. Science 350(6260):534-538 doi:10.1126/science.aab2210.

Starn, J. J. \& K. Belitz, 2018. Regionalization of Groundwater Residence Time Using $\begin{array}{llll}\text { Metamodeling. } & \text { Water } \quad \text { Resources } & \text { Research }\end{array}$ doi:10.1029/2017wr021531.

Steffen, W., K. Richardson, J. Rockstrom, S. E. Cornell, I. Fetzer, E. M. Bennett, R. Biggs, S. R. Carpenter, W. de Vries, C. A. de Wit, C. Folke, D. Gerten, J. Heinke, G. M. Mace, 
L. M. Persson, V. Ramanathan, B. Reyers \& S. Sorlin, 2015. Sustainability. Planetary boundaries: guiding human development on a changing planet. Science 347(6223):1259855 doi:10.1126/science.1259855.

Tesoriero, A. J. \& L. J. Puckett, 2011. O2reduction and denitrification rates in shallow aquifers. Water Resources Research 47(12) doi:10.1029/2011wr010471.

Tetzlaff, D., J. Seibert \& C. Soulsby, 2009. Inter-catchment comparison to assess the influence of topography and soils on catchment transit times in a geomorphic province; the Cairngorm mountains, Scotland. Hydro'^oic.l Processes 23(13):18741886 doi:10.1002/hyp.7318.

Thomas, Z. \& B. W. Abbott, 2018. Hedgerows reduce $n_{1 \iota}$ - tete flux at hillslope and catchment scales via root uptake and secondary effer is. 'ournal of Contaminant Hydrology 215:51-61 doi:https://doi.org/10.1016/i.jc .nt.yd.2018.07.002.

Thomas, Z., P. Rousseau-Gueutin, B. IV Abbott, T. Kolbe, H. Le Lay, J. Marçais, F. Rouault, C. Petton, P. Pichelin, T. Le Hennaff, H. Squividant, T. Labasque, J.-R. de Dreuzy, L. Aquilina, J. Ba’-1ry ‘̌ G. Pinay, 2019. Long-term ecological observatories needed to understand - cohydrological systems in the Anthropocene: a catchmentscale case study in $b_{1}{ }^{i+}$ any, France. Regional Environmental Change 19(2):363-377 doi:10.1007/s16:1 s-018-1444-1.

US EPA, 2008. Gulf Hypoxia Action Plan 2008 for Reducing, Mitigating, and Controlling Hypoxia in the Northern Gulf of Mexico and Improving Water Quality in the Mississippi River Basin. Mississippi River/Gulf of Mexico Watershed Nutrient Task Force.

Van Meter, K. J. \& N. B. Basu, 2015. Catchment legacies and time lags: a parsimonious watershed model to predict the effects of legacy storage on nitrogen export. PLoS One 10(5):e0125971 doi:10.1371/journal.pone.0125971. 
Van Meter, K. J. \& N. B. Basu, 2017. Time lags in watershed-scale nutrient transport: an exploration of dominant controls. Environmental Research Letters 12(8) doi:10.1088/1748-9326/aa7bf4.

Van Meter, K. J., N. B. Basu \& P. Van Cappellen, 2017. Two centuries of nitrogen dynamics: Legacy sources and sinks in the Mississippi and Susquehanna River Basins. Global Biogeochemical Cycles 31(1):2-23 doi:10.1002/2016gb005498.

Van Meter, K. J., N. B. Basu, J. J. Veenstra \& C. L. Burras, 2016. The nitrogen legacy: emerging evidence of nitrogen accumulation in a thropogenic landscapes. Environmental Research Letters 11(3) doi:10.1088 1/:'8-9326/11/3/035014.

Visser, A., H. P. Broers, R. Purtschert, J. Sültenfuß $\&$ \ ı. de Jonge, 2013. Groundwater age distributions at a public drinking water supriy :ell field derived from multiple age tracers $\left({ }^{85} \mathrm{Kr},{ }^{3} \mathrm{H} /{ }^{3} \mathrm{He}\right.$, and $\left.{ }^{39} \mathrm{Ar}\right)$. V/a. $\mathbf{r}$ Resources Research 49(11):7778-7796 doi:10.1002/2013wr014012.

Wendland, F., R. Kunkel, A. Grimva:' B. Kronvang \& D. I. Müller-Wohlfell, 2002. The SOIL-N/WEKU model management of diffust nitrogen leaching at the scale of river basins. Water Science and Technology 45(y, '’,5-292 doi:10.2166/wst.2002.0260.

Wyns, R., J. M. Baltas. ^t, P. Lachassagne, A. Legchenko, J. Vairon \& F. Mathieu, 2004. Application of proton magnetic resonance soundings to groundwater reserve mapping in weathered basement rocks (Brittany, France). Bulletin De La Societe Geologique De France 175(1):21-34 doi:10.2113/175.1.21. 


\section{CRediT author statement}

Camille Vautier: Conceptualization, Methodology, Formal analysis, Software, Writing Review \& Editing

Tamara Kolbe : Methodology, Investigation

Tristan Babey : Methodology, Investigation

Jean Marçais : Conceptualization, Methodology, Review \& Editing

Benjamin W. Abbott : Writing - Review \& Editing

Anniet M. Laverman : Conceptualization, Review \& Editing

Zahra Thomas : Investigation, Review \& Editing

Luc Aquilina : Conceptualization, Review \& Editing

Gilles Pinay : Conceptualization, Writing - Review \&́ Eaiing

Jean-Raynald de Dreuzy : Conceptualization, Meliudology, Writing - Review \& Editing 


\section{Declaration of interests}

$X$ The authors declare that they have no known competing financial interests or personal relationships that could have appeared to influence the work reported in this paper. 
Graphical abstract

Nitrogen input scenarios

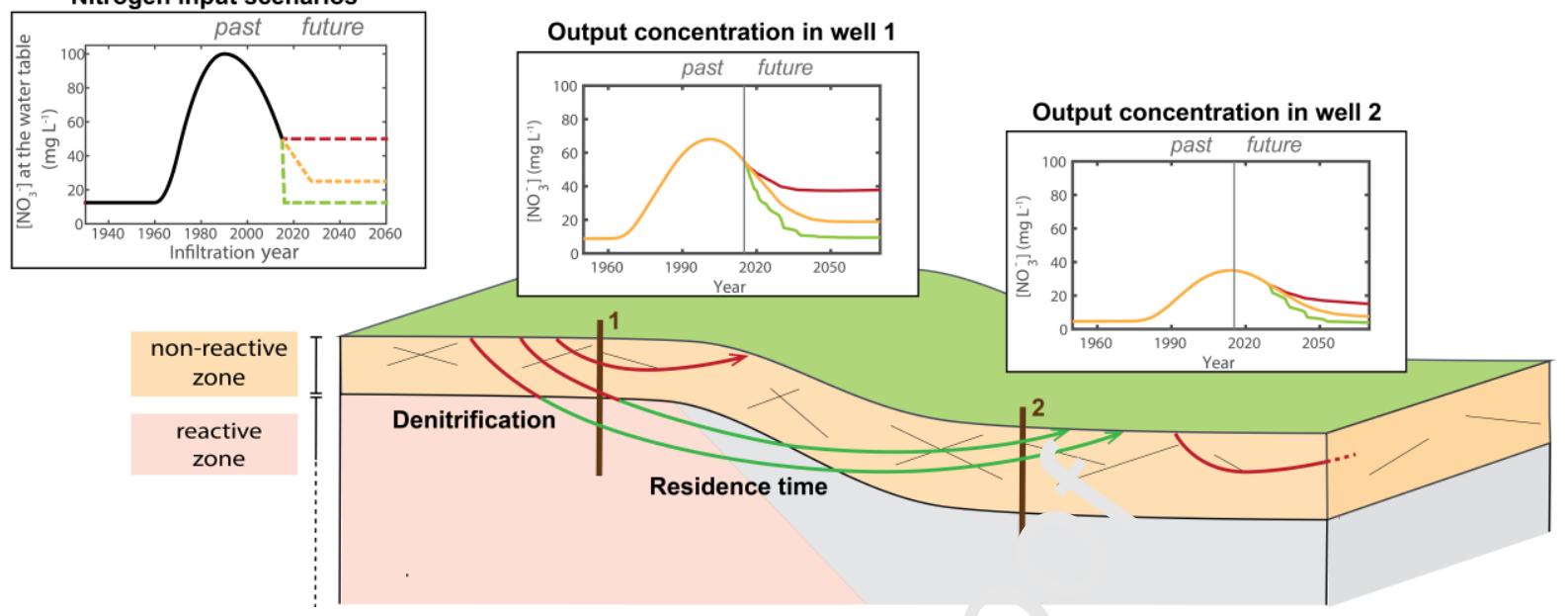




\section{Highlights}

- Nitrate recovery trajectories were predicted based on a few key-parameters.

- Two age tracers are necessary to predict groundwater nitrate concentration.

- The stratification of denitrification controls the nitrate dynamic in the aquifer.

- Uncertainty about past nitrogen inputs may not alter the predictions. 